\author{
AnNa Bieganowska-Skóra \\ Uniwersytet Marii Curie-Skłodowskiej w Lublinie \\ https://orcid.org/0000-0003-3097-7376
}

\title{
LUBLIN W PRACY PEDAGOGA - ZASOBY MIASTA W DZIAŁANIACH EDUKACYJNYCH. CZĘŚĆ 1. MUZEA
}

\begin{abstract}
Streszczenie: W niniejszym tekście przeanalizowano ofertę edukacyjną lubelskich muzeów. Próbowano dać odpowiedź na pytanie, czy planując oddziaływania edukacyjne, pracownicy placówek uwzględniają potrzeby młodego pokolenia oraz zalecenia dydaktyków, czy efekty ich pracy są dla dzieci i młodzieży atrakcyjne. Opis uzupełniono wykazami propozycji zajęć oferowanych uczniom przedszkoli i szkół przez placówki wchodzące w skład Muzeum Lubelskiego w Lublinie oraz Muzeum Wsi Lubelskiej, Muzeum na Majdanku i Regionalne Muzeum Cebularza.
\end{abstract}

Słowa kluczowe: edukacja muzealna, Lublin, przestrzeń miasta w edukacji

\section{WPROWADZENIE}

Z badań Jeana Twenge (za: Musiał 2016, s. 89) wynika, że współcześni uczniowie osiągają zdecydowanie gorsze wyniki w nauce niż ich rówieśnicy przed kilku laty. Fakt ten nie psuje jednak dzieciom i młodzieży dobrego samopoczucia, gdyż - jak dowiedziono - mają o sobie zdecydowanie wyższe mniemanie niż starsze pokolenia. Z problemem borykają się natomiast nauczyciele, wychowawcy i badacze edukacji, którzy od lat usiłują znaleźć odpowiedź na pytanie, jak zorganizować proces uczenia się i nauczania, aby młode pokolenie było zainteresowane nauką, angażowało się w edukację i, finalnie, „czegoś” się nauczyło.

Sprawia to pedagogom pewną trudność, ponieważ do instytucji edukacyjnych wkroczyli cyfrowi tubylcy, od kołyski zanurzeni w nowych technologiach, traktujący je jako jedyne okno na świat, główne źródło wiedzy. Dzieci i młodzież „urodzone z myszką w ręku" - pierwsze pokolenie homo mediens - nazywa się również pokoleniem C (Morbitzer 2012, s. 136; Morbitzer, brw). 
Dlatego też szkoła, operująca głównie słowem, kredą i tablicą, w tradycyjnej formie przestała być dla uczniów atrakcyjna (Bougsiaa, Kopciewicz, s. 142; Pezda 2011). Żeby sprostać wymogom dydaktyki i młodego pokolenia jednocześnie, nauczyciele poszukują nowych przestrzeni edukacyjnych. Mianem tym określa się oprócz szkoły i klasy, które przychodzą do głowy jako pierwsze skojarzenie, m.in.: dom rodzinny, teatr, bibliotekę, muzeum, las itd. Według najogólniejszej i nieco tautologicznej definicji przestrzeń edukacyjna to miejsce, w którym dokonują się procesy edukacyjne. Warto podkreślić, że - zdaniem Y-Fu Tuana - gdy się tę przestrzeń pozna, nada się jej wartość, od tej pory będzie miejscem (za: Myrdzik 2015, s. 14). Zaś według Edmunda Trempały (1996, s. 96) „przestrzeń i miejsce stanowią ważny element współczesnego świata, bowiem są nierozerwalnie związane z życiem człowieka. Miejsce jest początkiem i zakończeniem ludzkiego istnienia”. Dziś coraz częściej w roli takiej przestrzeni występuje miasto wraz z poszczególnymi jego elementami. Nie zawsze było to oczywiste.

\section{DLACZEGO MIASTO?}

Miasto obce było człowiekowi. Przyczyny: ogólnokulturalne [...]; społeczne [...];

fizjologiczne [...].

W naszej epoce przyczyny te zanikają. Zmienia się stosunek uczuciowy człowieka do miasta. $\mathrm{Na}$ podstawie tego nowego ustosunkowania może wyróść pojęcie nowego piękna.

(Peiper 1922, s. 23-31)

Aż do początków XX wieku przestrzeń miejska była wartościowana negatywnie: jako przeciwna naturze, a także właściwa nizinom społecznym siedziba zła i nierzadko rozpusty. W 1922 roku w manifeście Miasto. Masa. Maszyna Tadeusz Peiper nawoływał sobie współczesnych do zachwytu nad miastem, chciał utwierdzić ich w przekonaniu, że stało się ono naturalnym środowiskiem człowieka; symbolem kultury, postępu i nowoczesności. Poeta upatrywał w mieście źródeł „piękna nowego, nie dającego się porównać z żadnem innem, piękna o niewyczerpanem bogactwie zasobów i o zupełnie nieprzewidzianej możliwości wpływów” (Peiper 1922, s. 21). Po blisko stu latach hasła tego manifestu wydają się nadzwyczaj aktualne.

Żyjemy w mieście jak masa w rozumieniu Peipera (1922, s. 26): masa-społeczeństwo i masa-tłum, „które oddziaływają coraz silniej na świadomość człowieka”. Jeszcze większy niż w dwudziestoleciu międzywojennym wpływ na nasze życie wywierają maszyny. Są one - jak zapowiadał Peiper - dobrodziejstwem ludzkości, synonimem postępu; wszczepiły nas w „nurt nowoczesności”. Poeta nie przewidział tylko, że 
nieumiejętnie używane mogą być źródłem wielu zagrożeń oraz że świat współczesnych maszyn w sprytny sposób zdobędzie sobie Mickiewiczowski „rząd dusz” nad całym młodym pokoleniem. Tak więc można zaryzykować twierdzenie, że w Peiperowska struktura $3 x M$ nawet po stu latach, podczas których dokonał się postęp cywilizacyjny, jest doskonałym podłożem do rozwoju pokolenia $C$ i przyjaznym mu środowiskiem.

Z uwagi na podkreślany przez Justynę Pilarską (2017, s. 154; por. Mendel 2016, s. 79) fakt, iż lokalność, specyfika środowiska i jego atmosfera społeczno-kulturowa odgrywają dużą rolę w procesie kreowania tożsamości jednostkowych i społecznych, w niniejszym tekście miały zostać scharakteryzowane i ocenione zasoby edukacyjne Lublina w kontekście dopasowania ich do potrzeb współczesnych uczniów. Już pobieżna analiza materiału źródłowego wykazała, że należy zmodyfikować pierwotny zamysł. Zgromadzony materiał okazał się bardzo bogaty i nie sposób omówić wszystkich aspektów edukacyjnych przestrzeni miasta w jednym artykule. Dlatego też ograniczono się do analizy jednego z obszarów, a mianowicie placówek muzealnych, a pozostałe uczyniono tematem dociekań w kolejnych tekstach.

\title{
DLACZEGO LUBLIN?
}

\author{
Tatary - nie naród, \\ Graf - nie hrabia, \\ Czwartek - nie dzień, \\ Dziesiąta - nie godzina... \\ A wszystko to dziwy Lublina.
}

Tak anonimowy autor w 1907 roku na łamach jednodniówki „Urocza Lublinianka” zachwalał walory i uroki miasta. Do dziś żadne z wymienionych nie straciły na aktualności, a bez przesady można stwierdzić, że miasto wzbogaciło się o kolejne atrybuty. Jak donosi Wikipedia (główne źródło pozyskiwanej przez cyfrowych tubylców wiedzy), Lublin (po łacinie Lublinum) to największe na wschód od Wisły miasto w Polsce; dziewiąte pod względem wielkości populacji; szesnaste pod względem powierzchni (Lublin 2018). Jest stolicą województwa lubelskiego, centralnym ośrodkiem aglomeracji lubelskiej. Prawa miejskie otrzymał z rąk króla Władysława Łokietka w 1317 roku; był siedzibą Trybunału Koronnego; miejscem, w którym została podpisana Unia Lubelska; a nawet - przez krótki czas - stolicą Polski. Lublin dziś uchodzi przed wszystkim za miasto uniwersyteckie, a jego akademickie korzenie sięgają XVII wieku - wówczas powstała tu pierwsza uczelnia wyższa. Zajmuje też stałą, mocną pozycję na kulturalnej mapie Polski. Jak można przeczytać na oficjalnej stronie internetowej miasta (O mieście 2018), to w Lublinie odbywa się szereg renom- 
owanych międzynarodowych imprez i wydarzeń artystycznych, festiwali, przeglądów czy wystaw. Co istotne, część z nich jest kontynuacją śladów przeszłości, dziedzictwa kulturowego i historycznego. Pozostałe to wynik przemyśleń młodego pokolenia artystów, zgodnie ze stwierdzeniem, że w Lublinie „świadomość historii inspiruje przyszłość" (O mieście 2018). Przez specjalistów od wizerunku Lublin kreowany jest na miasto wiedzy i innowacyjności. Na dobre przylgnęło do niego określenie miasto inspiracji. Jako pedagog i rodowita lublinianka chciałam się przekonać, czy nasz lubelski genius loci przekłada się na locus educandi.

\section{DLACZEGO MUZEA?}

[...] sa talerze, ale nie ma apetytu. Są obrączki, ale nie ma wzajemności od co najmniej trzystu lat.

(Szymborska 1977, s. 58)

Według Słownika języka polskiego PWN muzeum to „instytucja gromadząca, przechowująca i konserwująca zbiory z różnych dziedzin kultury, sztuki, nauki lub techniki i udostępniająca je publiczności w formie wystaw". Pokoleniu dzisiejszych dorosłych kojarzy się z monumentalnym $\mathrm{z}$ reguły gmachem, w którym panuje wszechogarniająca cisza, filcowymi kapciami i hasłem „nie dotykać eksponatów”.

Współcześnie muzea przechodzą przemianę. Pełnią szereg ról wypunktowanych w art. 2, rozdz. 1 Ustawy o muzeach, spośród których najważniejsze, z punktu widzenia niniejszego opracowania, są: prowadzenie działalności edukacyjnej (stanowiącej zdaniem Renaty Pater (2017, s. 76) wizytówkę współczesnego muzealnictwa) oraz udostępnianie zbiorów do celów edukacyjnych i naukowych. Warto wspomnieć, że funkcję edukacyjną muzea miały od zarania swych dziejów, zanim jeszcze zyskały formę zinstytucjonalizowaną (Zduńczyk 2015, s. 169).

W odpowiedzi na potrzeby czasów muzea przestały być tylko depozytariuszami przeszłości; miejscami, w których - jak napisała Wisława Szymborska (1977, s. 58) „omszały woźny drzemie słodko | zwiesiwszy wąsy nad gablotką”. Stały się one ważną przestrzenią edukacji przyszłości; miejscem, w którym dochodzi do spotkania, dialogu; w którym człowiek nie tylko zwiedza i ogląda, ale również aktywnie współtworzy i konstruuje rzeczywistość, pogłębia i umacnia swoją tożsamość - narodową i regionalną; uczy się krytycznego myślenia, a także zaznaje rozrywki (por. Pater 2013, s. 58). Przestrzenie muzealne wypełniają się aparaturą multimedialną, która to umożliwia i ułatwia przekaz, a także czyni go atrakcyjnym. Oferta współczesnych muzeów jest personalizowana, dopasowywana do potrzeb różnych grup odbiorców, wyodrębnionych 
nie tylko na podstawie kryterium wiekowego (por. Nadolska-Styczyńska 2016, s. 96-97). Dużo uwagi poświęca się ostatnimi czasy na dostosowanie ekspozycji do potrzeb osób $\mathrm{z}$ różnego rodzaju niepełnosprawnościami, żeby każdy gość muzeum mógł je zwiedzać jak najbardziej efektywnie. Zwraca się uwagę na to, by praca edukacyjna w muzeach była zaplanowana, systematyczna, a także powiązana ze szkolnymi programami nauczania. Ale jak podkreśla Pater (2017, s. 76), obecnie „muzeum otwarte na społeczną edukację potrzebuje również szkoły otwartej na środowisko kulturowe życia każdego człowieka, otwartej i chętnej do współpracy z instytucjami kultury”. Ten rodzaj współpracy szkoły ze środowiskiem jest cenny również dla pedagogów: pomaga upoglądowić nauczanie, a także świadczy o kompetencjach zawodowych nauczyciela - udowadnia, że potrafi on właściwie wykorzystać czas i przestrzeń, co według Hanny Hamer (1994, s. 28-29) jest jedną z kompetencji dydaktycznych.

\section{OFERTA EDUKACYJNA LUBELSKICH MUZEÓW}

Jak zatem przedstawia się oferta edukacyjna lubelskich muzeów? Analizie poddano propozycje przygotowane przez Muzeum Lubelskie (Muzeum na Zamku, Muzeum Historii Miasta Lublina, Muzeum Józefa Czechowicza, Muzeum Dworek Wincentego Pola, Muzeum Martyrologii „Pod Zegarem”), Muzeum na Majdanku, Muzeum Wsi Lubelskiej oraz Regionalne Muzeum Cebularza.

Historia Muzeum Lubelskiego w Lublinie rozpoczęła się w 1901 roku, kiedy to zorganizowano dla mieszkańców dwie wystawy: przedmiotów i sztuki starożytności oraz przemysłowo-rolniczą. Dziś Muzeum jest instytucją kultury samorządu województwa lubelskiego współprowadzoną przez ministra kultury i dziedzictwa narodowego. Składa się z kilku filii i oddziałów, umiejscowionych również poza miastem.

Największą placówką i główną siedzibą jest Muzeum Na Zamku. Zbiory udostępniane zwiedzającym pogrupowane zostały w następujących segmentach:

- Dział Sztuki i Kultury Wizualnej,

- Dział Kultury Materialnej i Duchowej,

- Sekcja Archeologii,

- Sekcja Etnografii,

- Sekcja Rycin i Rysunków,

- Sekcja Numizmatyki,

- Sekcja Militariów,

- Dział Wydawnictw,

- Biblioteka.

Za przygotowanie i realizację oferty edukacyjnej odpowiada specjalnie powołana komórka - Dział Edukacji, któremu przyświeca następujący cel: „oswajanie 
najmłodszego pokolenia z muzeum jako miejscem przyjaznym i szczególnie interesującym” (Dział Edukacji... 2013).

Lekcje muzealne we wszystkich wymienionych placówkach są odpłatne, a ceny zajęć zróżnicowane w zależności od ich formy. Rezerwacji można dokonać telefonicznie, co z pewnością stanowi duże ułatwienie dla nauczycieli. Oferta skierowana jest do uczniów na wszystkich etapach edukacyjnych. Dla najmłodszych (przedszkolaków) przygotowano warsztaty wprowadzające w arkana muzealnictwa oraz poświęcone lubelskim legendom. Według opisu w trakcie zajęć przekazywana wiedza merytoryczna łączy się płynnie z działaniami praktycznymi - dzieci tworzą prace plastyczne oraz biorą udział w grze dydaktycznej rozgrywającej się w przestrzeni muzealnej. Identyczną ofertę Dział Edukacji proponuje uczniom klas I-III. Sam opis warsztatów nie daje możliwości oceny stopnia dostosowania treści do grupy wiekowej - w każdym przypadku wygląda identycznie. Dużo szerszy wachlarz tematyczny, bo składający się z aż 17 propozycji, skierowany jest do uczniów klas starszych (IV-VI). Na stronie odnajdujemy również listę zajęć muzealnych przyporządkowanych uczniom klasom gimnazjalnym - 18 tematów. Dla uczniów szkół średnich przewidziano 11 lekcji - tematy prawie całkowicie pokrywają się z tymi, które są proponowane młodszym grupom uczniów. W trakcie zajęć uczniowie mają szansę poszerzyć swoją wiedzę historyczną (zwłaszcza ukierunkowaną na lokalne elementy historii Polski), ale też cywilizacyjną. Zapoznają się ze staropolskimi zwyczajami, śledzą losy chińskiej porcelany czy jedwabnego szlaku, poznają obyczaje panujące na dworach królewskich.

Uczestnicy zajęć zdobywają wiedzę o przeszłości, rozwiązując krzyżówki, wypełniając karty pracy, przygotowując prace plastyczne różnymi technikami (malowania, lepienia, budowania twierdzy, projektowania strojów itd.). Tematy zajęć skonstruowane zostały tak, by możliwe było wykorzystanie infrastruktury Muzeum oraz profilu zgromadzonych kolekcji. Jest w nich bardzo dużo odwołań do ważnych momentów w historii miasta. W razie potrzeby można zamówić warsztaty poświęcone wyłącznie kulturze regionu lub historii Lublina. Wątpliwości budzi jedynie pytanie, czy zajęcia, których „zwieńczeniem jest układanie puzzli”, będą faktycznie atrakcyjne dla współczesnych nastolatków.

Na potrzeby współczesności odpowiada troska o udostępnianie zbiorów muzealnych uczniom z niepełnosprawnościami. Muzeum współpracuje w tym zakresie z Fundacją Kultury bez Barier. Szczegółowe opisy dostępnych ułatwień można znaleźć w oddzielnej zakładce z informacjami dotyczącymi owego zagadnienia (warto wspomnieć, że spośród analizowanych placówek muzealnych tylko Muzeum na Zamku poświęciło wzmiankowanej kwestii oddzielny fragment strony internetowej). Osobom z niepełnosprawnością ruchową zapewniony jest wygodny dostęp do budynku. Mają one możliwość dojazdu pod sam zamek i mogą korzystać 
z oznakowanych miejsc parkingowych, podjazdów, wind wewnątrz budynku. Dla osób z niepełnosprawnością słuchu przygotowane zostały audioprzewodniki $\mathrm{z}$ indywidualną pętlą indukcyjną i film o Muzeum z tłumaczeniem na język migowy, a dla osób z niepełnosprawnością wzroku - audiodeskrypcje wybranych obiektów. Są one dostępne w dwóch formach: jako pliki zamieszczone na stronie internetowej i wypożyczane na czas zwiedzania Muzeum audioprzewodniki. Osoby niewidome i słabowidzące mają również do dyspozycji tyflografiki. W trakcie lekcji muzealnych wykorzystuje się je razem $\mathrm{z}$ drukami reliefowymi i nagraniami binauralnymi.

Tabela 1. Oferta edukacyjna Muzeum na Zamku

\begin{tabular}{|c|c|}
\hline \multicolumn{2}{|r|}{ Muzeum na Zamku } \\
\hline Odpłatność & $\begin{array}{l}\text { sale muzealne: jednorazowa opłata za lekcję ( } 55 \mathrm{zł}) \text { plus } 5-10 \mathrm{zł} / \mathrm{os} \text {.; } \\
\text { sala odczytowa (zajęcia z pokazem multimedialnym lub filmem): } \\
\text { jednorazowa opłata ( } 60 \mathrm{zł})\end{array}$ \\
\hline Liczebność grup & 15 osób (warsztaty), 20 osób (lekcje muzealne) \\
\hline Metody i formy & $\begin{array}{l}\text { prezentacje multimedialne, filmy, warsztaty plastyczne, elementy gry } \\
\text { i zabawy, karty pracy }\end{array}$ \\
\hline Cykliczność & zajęcia jednorazowe i cykle lekcji muzealnych \\
\hline \multicolumn{2}{|r|}{ Oferta } \\
\hline Przedszkola & $\begin{array}{l}\text { „Poznajemy Muzeum” } \\
\text { „Legendy lubelskie” }\end{array}$ \\
\hline Szkoły podstawowe & $\begin{array}{l}\text { Klasy I-III szkoły podstawowej } \\
\text { „Poznajemy Muzeum } \\
\text { „Legendy lubelskie” } \\
\text { Klasy IV-VI szkoły podstawowej } \\
\text { „Portret króla” } \\
\text { „W pracowni malarza” } \\
\text { „Najstarsze zabytki wzgórza zamkowego” } \\
\text { „Jak mistrz Matejko malował obraz Unia Lubelska?” } \\
\text { „Królowie na Zamku Lubelskim” } \\
\text { „Legendy lubelskie” } \\
\text { „Lublin Jagielloński” } \\
\text { „Jedwabne opowieści z krainy Orientu” } \\
\text { „Średniowieczny Zamek Lubelski - jak zbudować rezydencję dla króla } \\
\text { i rycerską twierdzę?” } \\
\text { „Jak ubierano się w dawnej Polsce?” } \\
\text { „Ile jest warte szlacheckie słowo, czyli tradycje i obyczaje szlacheckie” } \\
\text { „Poszukiwacze skarbów” }\end{array}$ \\
\hline
\end{tabular}




\begin{tabular}{|c|c|}
\hline \multicolumn{2}{|r|}{ Oferta } \\
\hline Szkoły podstawowe & $\begin{array}{l}\text { „O zwierzętach i ludziach w dawnych i nieco nowszych czasach” } \\
\text { „Serce nie sługa” } \\
\text { „Święci z kalendarza” } \\
\text { „Od codziennego przedmiotu do muzealnego eksponatu” } \\
\text { „Skąd wzięła się szopka bożonarodzeniowa?" }\end{array}$ \\
\hline Gimnazja & $\begin{array}{l}\text { „Portret króla” } \\
\text { „Malujemy jak mistrz” } \\
\text { „W pracowni malarza” } \\
\text { „Konterfekt - portret dawnego Polaka” } \\
\text { „Kwiaty z holenderskiego ogrodu” } \\
\text { „Co to jest rzeźba? Figurki z gliny i porcelany w zbiorach Muzeum” } \\
\text { „Najstarsze zabytki wzgórza zamkowego” } \\
\text { „Jak mistrz Matejko malował obraz Unia Lubelska?” } \\
\text { „Królowie na Zamku Lubelskim” } \\
\text { „Legendy lubelskie” } \\
\text { „Lublin Jagielloński" } \\
\text { „W krainie porcelany” } \\
\text { „Jedwabne opowieści z krainy Orientu” } \\
\text { „Sredniowieczny Zamek Lubelski - jak zbudować rezydencję dla króla } \\
\text { i rycerską twierdzę?” } \\
\text { „Jak ubierano się w dawnej Polsce?” } \\
\text { „Ile jest warte szlacheckie słowo, czyli tradycje i obyczaje szlacheckie” } \\
\text { „Tajniki dawnych rzemiosł” } \\
\text { zajęcia poświęcone kulturze regionu i historii Lublina (np. „Unia } \\
\text { Lubelska 1569”) }\end{array}$ \\
\hline Szkoły średnie & $\begin{array}{l}\text { „Najstarsze zabytki wzgórza zamkowego” } \\
\text { „Lublin Jagielloński” } \\
\text { „Jak ubierano się w dawnej Polsce?” } \\
\text { „Ile jest warte szlacheckie słowo, czyli tradycje i obyczaje szlacheckie” } \\
\text { „Konterfekt - portret dawnego Polaka” } \\
\text { „Kwiaty z holenderskiego ogrodu” } \\
\text { „Królowie na Zamku Lubelskim” } \\
\text { „Jedwabne opowieści z krainy Orientu” } \\
\text { „Średniowieczny Zamek Lubelski - jak zbudować rezydencję dla króla } \\
\text { i rycerską twierdzę?” } \\
\text { „Tajniki dawnych rzemiosł” } \\
\text { zajęcia poświęcone kulturze regionu i historii Lublina (np. tradycjom } \\
\text { bożonarodzeniowym na lubelskiej wsi) }\end{array}$ \\
\hline Inne & $\begin{array}{l}\text { specjalne zajęcia dla maturzystów obejmujące wykłady z historii, } \\
\text { historii sztuki oraz języka polskiego } \\
\text { zajęcia wakacyjne „Lato w muzeum” } \\
\text { zajęcia dla słuchaczy Uniwersytetu Trzeciego Wieku } \\
\text { możliwość zorganizowania tematycznych urodzin na zamku }\end{array}$ \\
\hline
\end{tabular}

Źródło: opracowanie własne na podstawie informacji z oficjalnej strony internetowej Muzeum na Zamku (Edukacja 2013). 
Muzeum Historii Miasta Lublina jest muzeum tematycznym, a więc znajdują się w nim eksponaty związane z wąskim obszarem zainteresowań. Mieści się w Bramie Krakowskiej - najbardziej charakterystycznym budynku Lublina - i gromadzi materiały dokumentujące historię miasta: od zabytków archeologicznych przez czasopisma i wydawnictwa aż po materiały dokumentujące historię lubelskiego przemysłu. Tej tematyce podporządkowane są również oferowane lekcje i warsztaty muzealne proponowane różnym grupom wiekowym. Młodsi na dedykowanych im zajęciach zdobywają wiedzę teoretyczną z zakresu historii Lublina, przygotowują prace plastyczne (ilustrują legendy, lepią fragment sklepienia renesansowego czy element muru Bramy), inscenizacje. Starsi wysłuchują wykładów ilustrowanych prezentacjami multimedialnymi, przy okazji oglądając oryginalne materiały źródłowe (dokumentację architektoniczną, fotografie). Interakcja z uczestnikami pojawia się w trakcie zajęć praktycznych, podczas których nie są jednak wykorzystywane możliwości wirtualnego świata.

Tabela 2. Oferta edukacyjna Muzeum Historii Miasta Lublina

\begin{tabular}{|c|c|}
\hline \multicolumn{2}{|r|}{ Muzeum Historii Miasta Lublina } \\
\hline Odpłatność & lekcja muzealna: 40 zł plus koszt biletów $4,50-5,50$ zł/os. \\
\hline Liczebność grup & 10-20 osób \\
\hline Metody i formy & $\begin{array}{l}\text { warsztaty plastyczne, inscenizacje, praca } \mathrm{z} \text { tekstem, prezentacje multimedialne, } \\
\text { wykłady }\end{array}$ \\
\hline Cykliczność & zajęcia jednorazowe \\
\hline \multicolumn{2}{|r|}{ Oferta } \\
\hline Przedszkola & $\begin{array}{l}\text { „Legendy miasta Lublina” } \\
\text { „Czy to sztuka być sztukatorem? Warsztaty lepienia renesansowego sklepienia” } \\
\text { „Krzywa wieża w Lublinie? Poznajemy tajemnice Bramy Krakowskiej” }\end{array}$ \\
\hline Szkoły podstawowe & $\begin{array}{l}\text { „Legendy miasta Lublina” } \\
\text { „O polskich królach w lubelskich murach” } \\
\text { „Krzywa wieża w Lublinie? Poznajemy tajemnice Bramy Krakowskiej” } \\
\text { „Czy to sztuka być sztukatorem? Warsztaty lepienia renesansowego sklepienia” }\end{array}$ \\
\hline Gimnazja & $\begin{array}{l}\text { "Lublin - miasto w murach” } \\
\text { „Czy to sztuka być sztukatorem? Warsztaty lepienia renesansowego sklepienia” } \\
\text { „Lublin w czasach Bolesława Prusa” }\end{array}$ \\
\hline Szkoły średnie & $\begin{array}{l}\text { „Lublin - miasto w murach” } \\
\text { „Zabytki renesansu lubelskiego" } \\
\text { „Poznajemy style i zabytki Lublina” } \\
\text { „Lublin w czasach Bolesława Prusa” } \\
\text { „Słoneczne Wzgórza - Lubelska Spółdzielnia Mieszkaniowa” }\end{array}$ \\
\hline Inne & $\begin{array}{l}\text { zajęcia dla studentów i dorosłych - propozycje takie same jak dla szkół ponadgim- } \\
\text { nazjalnych }\end{array}$ \\
\hline
\end{tabular}

Źródło: opracowanie własne na podstawie informacji z oficjalnej strony internetowej Muzeum Historii Miasta Lublina (Oferta edukacyjna 2013a). 
W kolejnej filii Muzeum Lubelskiego, Muzeum Literackim im. Józefa Czechowicza, zwiedzający i uczestnicy zajęć edukacyjnych mają możliwość poznania Lublina z poetyckiej perspektywy. Celem proponowanych lekcji, warsztatów i prelekcji jest „rozwijanie wrażliwości estetycznej młodzieży, inspirowanie samodzielnej refleksji nad tekstem literackim oraz pielęgnowanie tradycji regionalnych, a tym samym pogłębianie i umacnianie tożsamości lokalnej" (Oferta edukacyjna 2013b). Oferta obejmuje lekcje muzealne przede wszystkim dla uczniów klas starszych szkoły podstawowej oraz szkół ponadpodstawowych. Dzieciom młodszym proponuje się aktywne poznawanie Muzeum poprzez uczestnictwo w zabawach edukacyjnych i zajęciach plastycznych. Można wybrać także lekcje muzealne, które ułatwiają starszym uczniom zwiedzanie ekspozycji oraz zajęcia o tematyce związanej bezpośrednio z indywidualnymi zainteresowaniami osób zatrudnionych w placówce (informacja pozyskana od pracownika Muzeum podczas rozmowy telefonicznej). Oferta nie jest bardzo szeroka, co wynika z profilu instytucji. Unowocześnienie pracy edukacyjnej, jak można przeczy tać na stronie ML, polega głównie na wykorzystywaniu w trakcie zajęć sprzętu audiowizualnego, który ma zwiększyć atrakcyjność oraz różnorodność przekazu.

Tabela 3. Oferta edukacyjna Muzeum Literackiego im. Józefa Czechowicza

\begin{tabular}{|l|l|}
\hline \multicolumn{2}{|c|}{ Muzeum Literackie im. Józefa Czechowicza } \\
\hline Odpłatność & lekcja muzealna: 40 zł plus koszt biletów 4,50-5,50 zł/os. \\
\hline Liczebność grup & $10-20$ osób \\
\hline Metody i formy & praca z tekstem, prezentacje multimedialne, gry dydaktyczne \\
\hline Cykliczność & zajęcia jednorazowe \\
\hline \multicolumn{2}{|c|}{ Oferta } \\
\hline $\begin{array}{l}\text { Przedszkola } \\
\text { i klasy I-III }\end{array}$ & $\begin{array}{l}\text { zajęcia dotyczące wierszy lubelskich poetów: Józefa Czechowicza, Franciszki Arn- } \\
\text { sztajnowej, Anny Kamieńskiej, Janiny Porazińskiej }\end{array}$ \\
\hline $\begin{array}{l}\text { Klasy IV-VIII } \\
\text { szkoły } \\
\text { podstawowej } \\
\begin{array}{l}\text { Gimnazja } \\
\text { Szkoły średnie }\end{array}\end{array}$ & $\begin{array}{l}\text { „Poezja głuchego cierpienia i radości naiwnej. Motyw Arkadii i Apokalipsy w twór- } \\
\text { "Miasto poetów. Życie literackie Lublina w okresie dwudziestolecia międzywojennego” } \\
\text { "Tobie śpiewam Lublinie.... Życie i dorobek literacki Franciszki Arnsztajnowej” }\end{array}$ \\
\hline Inne & $\begin{array}{l}\text { zajęcia bezpośrednio związane z zainteresowaniami pracowników, np. dotyczącymi } \\
\text { tradycji bożonarodzeniowych, czy lekcje o starych globusach, mapach nieba itp. }\end{array}$ \\
\hline
\end{tabular}

Źródło: opracowanie własne na podstawie informacji z oficjalnej strony internetowej Muzeum Literackiego im. Józefa Czechowicza (Oferta edukacyjna 2013b).

Podobną placówką jest Muzeum Dworek Wincentego Pola. Mieści się ono w modrzewiowym osiemnastowiecznym dworku, który należał do ojca poety. Oferuje cykl warsztatów, prelekcji, pogadanek i wykładów poruszających szereg kwestii kulturalnych, społecznych, obyczajowych, geograficznych. Klamrą spinającą różnorodne 
tematy jest osoba patrona Muzeum - Wincentego Pola. Z informacji uzyskanych w placówce wynika, że oferta przygotowana została dla uczniów klas starszych, ale w miarę potrzeb pracownicy dostosowują zajęcia do możliwości percepcyjnych najmłodszych zwiedzających, którzy bardzo chętnie odwiedzają dworek. Uatrakcyjnienie zwiedzania polega na wprowadzeniu elementów gier i zabaw dydaktycznych.

Tabela 4. Oferta edukacyjna Muzeum Dworek Wincentego Pola

\begin{tabular}{|c|c|}
\hline \multicolumn{2}{|r|}{ Muzeum Dworek Wincentego Pola } \\
\hline Odpłatność & lekcja muzealna: 40 zł plus koszt biletu ulgowego dla każdego uczestnika - 4,50 zł \\
\hline Liczebność grup & do 25 osób \\
\hline Metody i formy & lekcje warsztatowe, gry i zabawy dydaktyczne \\
\hline Cykliczność & zajęcia jednorazowe \\
\hline \multicolumn{2}{|r|}{ Oferta } \\
\hline $\begin{array}{l}\text { Przedszkola } \\
\text { i klasy I-III }\end{array}$ & $\begin{array}{l}\text { oferta muzeum skierowana jest do uczniów starszych, natomiast jeśli zaistnieje po- } \\
\text { trzeba, pracownicy adaptują propozycje tematów lekcji muzealnych do potrzeb dzieci } \\
\text { w wieku przedszkolnym oraz uczniów klas I-III }\end{array}$ \\
\hline $\begin{array}{l}\text { Klasy IV-VIII } \\
\text { szkoły } \\
\text { podstawowej } \\
\text { Gimnazja } \\
\text { Szkoły średnie }\end{array}$ & $\begin{array}{l}\text { „Życie i twórczość Wincentego Pola” - oprowadzanie kuratorskie po wystawie stałej } \\
\text { „Wincenty Pol - romantyk czy pozytywista?” - pogadanka } \\
\text { Pieśni Janusza, Pieśń o ziemi naszej, Rok myśliwca, Mohort - wspólna głośna lektura } \\
\text { i omawianie fragmentów najważniejszych dzieł Wincentego Pola } \\
\text { „Z Wincentym Polem po górach, dolinach” - zajęcia warsztatowe na temat języka } \\
\text { poety-geografa i jego zainteresowań naukowych } \\
\text { „Listy z ziemi naszej” - warsztaty z epistolografii } \\
\text { „Od dźwięku do słowa” - pogadanka na temat życia i twórczości Fryderyka Chopina, } \\
\text { związków Wincentego Pola z kompozytorem, a także miejsca muzyki w życiu poety } \\
\text { „Dwór polski - architektura, wnętrza, otoczenie” - ilustrowany odczyt poświęcony } \\
\text { genezie i dziejom dworów i dworków } \\
\text { „Dwory i dworki w literaturze” - zajęcia przybliżające obrazy dworów polskich na } \\
\text { podstawie wybranych dzieł: Pana Tadeusza Adama Mickiewicza, Lalki Bolesława } \\
\text { Prusa, Nad Niemnem Elizy Orzeszkowej, Doliny Issy Czesław Miłosza } \\
\text { „Śluby we dworze” - warsztaty z twórczością komediową Aleksandra Fredry } \\
\text { „Tradycje okresu Bożego Narodzenia” - pogadanka } \\
\text { „Tradycje okresu Wielkiej Nocy” - pogadanka } \\
\text { „Poznawcze pasje Wincentego Pola” - odczyt przedstawiający rozległość i różnorod- } \\
\text { ność zainteresowań patrona Muzeum, jego ciekawość świata i zaangażowanie w zdo- } \\
\text { bywanie wiedzy pomimo różnej natury trudności } \\
\text { „Podróże Wincentego Pola” - pogadanka przy mapie } \\
\text { „Wincenty Pol - naturalista” - pogadanka } \\
\text { „Globusy dawne, nowe i niezwykłe” - zajęcia popularyzujące wiedzę z zakresu karto- } \\
\text { grafii globusowej, prezentujące muzealną kolekcję globusów i pokazujące dydaktyczne } \\
\text { możliwości wykorzystania globusów } \\
\text { „Młody muzealnik” - zajęcia przybliżające w zabawowej formie prace prowadzone na } \\
\text { zapleczu Muzeum: tworzenie kolekcji, opracowywanie zbiorów czy organizację wystaw }\end{array}$ \\
\hline
\end{tabular}

Źródło: opracowanie własne na podstawie informacji z oficjalnej strony internetowej Muzeum Dworek Wincentego Pola (Oferta edukacyjna 2013c). 
Ostatnia z analizowanych placówek wchodzących w skład Muzeum Lubelskiego to Muzeum Martyrologii „Pod Zegarem”, którego oferta skierowana jest do uczniów starszych i obejmuje cztery propozycje jednorazowych lekcji muzealnych i wykładów. Bardzo mocno akcentuje się w nich regionalność - każdy z tematów ma związek z historią okupacyjnego Lublina. Siedziba Muzeum mieści się w celach byłego aresztu gestapo. Zwiedzającym udostępnia się dokumenty więźniów politycznych, pamiątki po więźniarkach KL Ravensbrück, multimedialne relacje świadków i więźniów oraz ich rodzin. Forma przekazu jest tradycyjna.

Tabela 5. Oferta edukacyjna Muzeum Martyrologii „Pod Zegarem”

\begin{tabular}{|l|l|}
\hline \multicolumn{2}{|c|}{ Muzeum Martyrologii „Pod Zegarem” } \\
\hline Odpłatność & lekcja muzealna, wykład: 40 zł \\
\hline Liczebność grup & do 30 osób \\
\hline Metody i formy & lekcja muzealna, wykład \\
\hline Cykliczność & zajęcia jednorazowe \\
\hline \multicolumn{2}{|c|}{ Oferta } \\
\hline $\begin{array}{l}\text { Klasy IV-VIII szkół } \\
\text { podstawowych } \\
\begin{array}{l}\text { Gimnazja } \\
\text { Szkoły średnie }\end{array}\end{array}$ & $\begin{array}{l}\text { „Więzienie na Zamku Lubelskim w latach 1939-1954” } \\
\text { "Grażyna Chrostowska - lubelska poetka, przedstawicielka pokolenia Kolumbów” }\end{array}$ \\
\hline
\end{tabular}

Źródło: opracowanie własne na podstawie informacji z oficjalnej strony internetowej Muzeum Martyrologii „Pod Zegarem” (Lekcje muzealne i wykłady 2013).

Najszerszą ofertę zajęć edukacyjnych proponuje Muzeum Wsi Lubelskiej. Dysponuje ono ogromną i bardzo różnorodną przestrzenią. Zajęcia, w zależności od tematu, odbywają się w replice budynku dawnego ratusza, miasteczkowej szkole, zagrodzie wiejskiej, dworze ziemiańskim, na muzealnym polu, w kuchni sprzed wieku, olejarni, chałupie tkacza czy garncarza, starej kuźni i wiatraku. Jak zaznaczają autorzy scenariuszy i jednocześnie prowadzący warsztaty, istotą zajęć jest łączenie nauki z zabawą. Scenariusze zaprojektowane zostały tak, by zabytki mogły „opowiedzieć” swoje historie, a archiwalia - „przemówić”. Uczestnicy „mają możliwość dotykania, a nawet brania do ręki rekwizytów. Instalacje - zaaranżowane układy przestrzenne - wyobrażają poszczególne sytuacje i problemy, eliminując wątpliwą w przypadku ukazywania przeszłości historycznej skuteczność narracji i werbalnego opisu" (Oferta 2019). Uczniowie, niezależnie od etapu edukacyjnego, zdobywają wiedzę na temat tego, co minione: dawnych tradycji, zwyczajów dnia codziennego ludzi różnych stanów, typowych czynności rzemieślniczych (uprawy lnu, pieczenia chleba) i etosu pracy rzemieślników, a także rozwoju cywilizacji i techniki. Dowiadują się, jak prały prababki, jak dawniej dbano o higienę; 
biorą udział w grach edukacyjnych i terenowych; samodzielnie przygotowują różne przedmioty, np. wielkanocne pisanki, kwiaty z bibuły czy kolorowe pająki; wędzą kiełbasę, wypiekają chleb. Niektóre zajęcia odbywają się tylko sezonowo uzależnione są od okresu wegetacyjnego roślin bądź kalendarza pracy rolników. Oferta została dopasowana do odbiorcy - w opisach zajęć precyzyjnie określono ich potencjalnego uczestnika. Analizując propozycje przygotowane przez pracowników Muzeum, można odnieść wrażenie, że wszystko - łącznie z językiem wypowiedzi - zostało bardzo dokładnie przemyślane i zaprojektowane z uwzględnieniem potrzeb i możliwości percepcyjnych uczestników zajęć. Skansen oferuje zajęcia jednorazowe, ścieżki edukacyjne oraz cykle zajęć. Szczegóły oferty edukacyjnej Muzeum zamieszczone zostały tabeli 6 .

Tabela 6. Oferta edukacyjna Muzeum Wsi Lubelskiej

\begin{tabular}{|c|c|}
\hline \multicolumn{2}{|r|}{ Muzeum Wsi Lubelskiej } \\
\hline Odpłatność & opłata uzależniona jest od rodzaju zajęć i waha się od 6 do 12 zł za osobę \\
\hline Liczebność grup & do $22-25$ osób \\
\hline Metody i formy & $\begin{array}{l}\text { warsztaty plastyczne i techniczne, gry i zabawy dydaktyczne, inscenizacje, ścieżki } \\
\text { edukacyjne }\end{array}$ \\
\hline Cykliczność & zajęcia jednorazowe i cykle lekcji muzealnych \\
\hline \multicolumn{2}{|r|}{ Oferta } \\
\hline Przedszkola & $\begin{array}{l}\text { „Budujemy Lublin - żywa gra edukacyjna” } \\
\text { „Drogi i place, furty i bramy - dlaczego to wozy jeździły po wsiach i miasteczkach?” } \\
\text { „Kuchnia - nasza codzienna troska, ciepło i bezpieczeństwo” } \\
\text { „Budujemy dom - zajęcia edukacyjne z elementami dźwiękowymi” } \\
\text { „Kolorowe Święta Wielkanocne” (sześciolatki) } \\
\text { „Prace w polu i w zagrodzie - droga chleba” (sześciolatki) } \\
\text { „Ginące zawody na muzealnej Wyżynie Lubelskiej” (sześciolatki) } \\
\text { „Salon i izba” (sześciolatki) } \\
\text { „Zabawki moich dziadków” } \\
\text { „Kijanką i na tarze, czyli jak prały nasze prababcie” (pięcio-, sześciolatki) } \\
\text { „Plastyka obrzędowa - ozdoby choinkowe” (sześciolatki) } \\
\text { „Spotkanie ze świętym Mikołajem” }\end{array}$ \\
\hline $\begin{array}{l}\text { Szkoły } \\
\text { podstawowe }\end{array}$ & $\begin{array}{l}\text { Klasy I-III szkoły podstawowej } \\
\text { „Budujemy Lublin - żywa gra edukacyjna” } \\
\text { „Drogi i place, furty i bramy - dlaczego to wozy jeździły po wsiach i miasteczkach” } \\
\text { (klasy I-II) } \\
\text { „Kuchnia - nasza codzienna troska, ciepło i bezpieczeństwo” (klasy I-II) } \\
\text { „Budujemy dom - zajęcia edukacyjne z elementami dźwiękowymi” (klasy I-II) } \\
\text { „Prace w polu i w zagrodzie - droga chleba” (klasy I-II) } \\
\text { „Od łuczywa do żarówki” (klasy II-III) } \\
\text { „Salon i izba” (klasy I-III) } \\
\text { „Zabawki moich dziadków” (klasy I-III) } \\
\text { „W Wojtusiowej izbie” (klasy II-III) }\end{array}$ \\
\hline
\end{tabular}




\begin{tabular}{|c|c|}
\hline \multicolumn{2}{|r|}{ Oferta } \\
\hline $\begin{array}{l}\text { Szkoły } \\
\text { podstawowe }\end{array}$ & 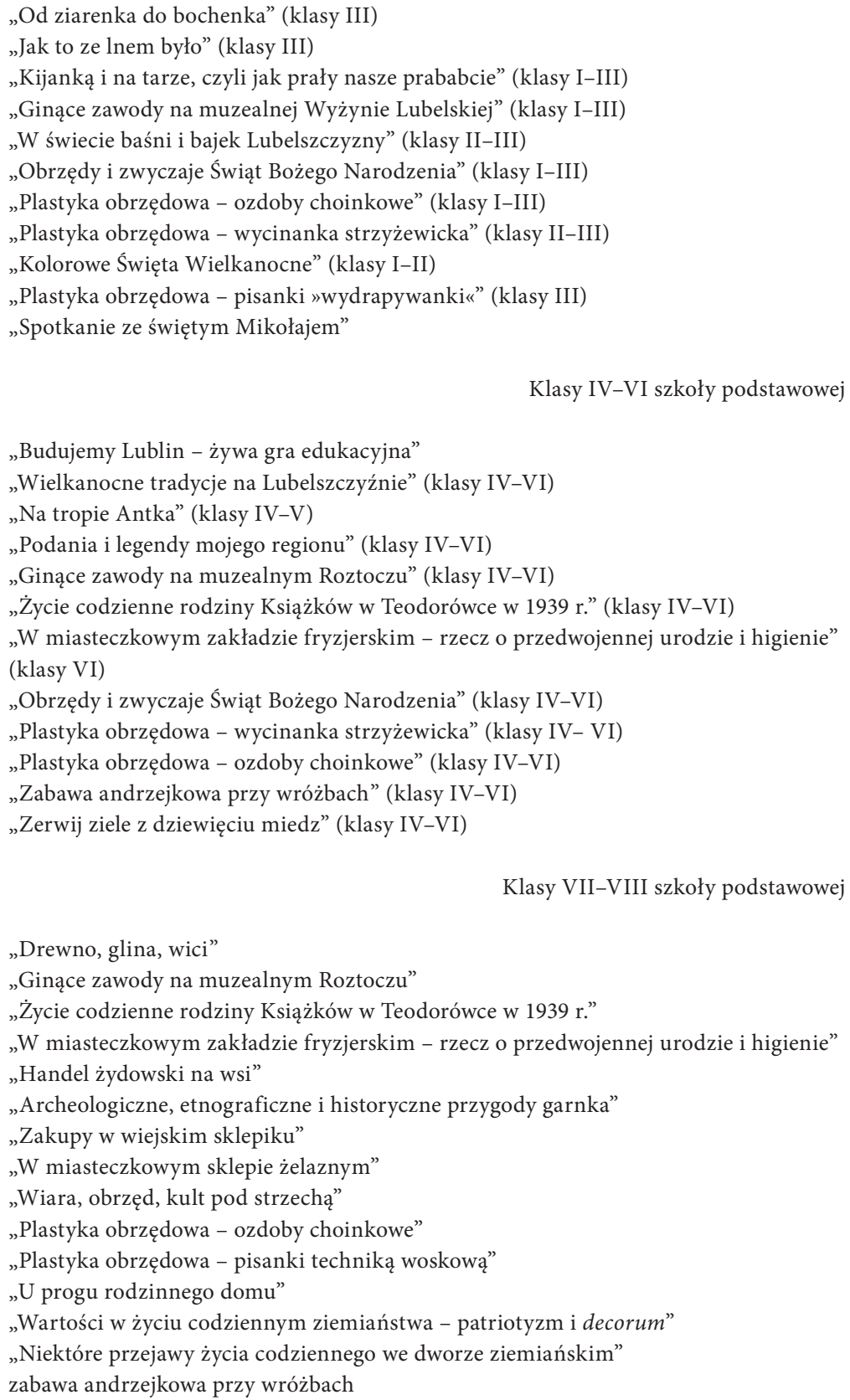 \\
\hline Gimnazja & $\begin{array}{l}\text { oferta taka sama jak dla uczniów klas VII-VIII plus: } \\
\text { „Kapliczki przydrożne - święte znaki ludowej pobożności” }\end{array}$ \\
\hline
\end{tabular}




\begin{tabular}{|c|c|}
\hline \multicolumn{2}{|r|}{ Oferta } \\
\hline Szkoły średnie & $\begin{array}{l}\text { „Ginące zawody na muzealnym Roztoczu” } \\
\text { „Życie codzienne rodziny Książków w Teodorówce w } 1939 \text { r.” } \\
\text { „Handel żydowski na wsi” } \\
\text { „Archeologiczne, etnograficzne i historyczne przygody garnka” } \\
\text { „Zakupy w wiejskim sklepiku” } \\
\text { „W miasteczkowym sklepie żelaznym” } \\
\text { „Zabawa z księżycami na } 6 \text { par” } \\
\text { „Kapliczki przydrożne - święte znaki ludowej pobożności” } \\
\text { „Wigilia w skansenie” } \\
\text { „Plastyka obrzędowa - ozdoby choinkowe” } \\
\text { „Śniadanie wielkanocne w skansenie” } \\
\text { „Plastyka obrzędowa - pisanki techniką woskową" } \\
\text { „U progu rodzinnego domu” } \\
\text { „Wartości w życiu codziennym ziemiaństwa - patriotyzm i decorum” } \\
\text { „Niektóre przejawy życia codziennego we dworze ziemiańskim” } \\
\text { zabawa andrzejkowa przy wróżbach }\end{array}$ \\
\hline Inne & $\begin{array}{l}\text { zajęcia edukacyjne przeznaczone dla seniorów } \\
\text { warsztaty „Poznajemy dziedzictwo kulturowe regionu - Muzeum szkole” (w ofercie } \\
\text { trzygodzinne ścieżki edukacyjne: „Przygotowanie tradycyjnego wiejskiego pożywie- } \\
\text { nia”, „Śladami ginących zawodów i umiejętności”, „Śladami przemysłu ludowego”) } \\
\text { warsztaty rękodzieła (m.in. pisania ikon, wyrobu pająka z bibuły, wycinanki, malowa- } \\
\text { nia skrzyni) dla uczniów klas III-VIII } \\
\text { warsztaty „Codzienność Żyda na wsi” w ramach projektu „Poznaj i uszanuj codzien- } \\
\text { ność innych” }\end{array}$ \\
\hline
\end{tabular}

Źródło: opracowanie własne na podstawie informacji z oficjalnej strony internetowej Muzeum Wsi Lubelskiej (Edukacja 2019).

Kolejna poddana analizie placówka - Państwowe Muzeum na Majdanku - powstała w listopadzie 1944 roku na terenie byłego niemieckiego obozu koncentracyjnego. „Misją Muzeum jest pielęgnowanie pamięci i rozwijanie edukacji historycznej o okupacji niemieckiej na Lubelszczyźnie podczas II wojny światowej" (O Muzeum). Założenia te realizuje się poprzez działalność wystawienniczą, edukacyjną i naukową. Na stronie internetowej w zakładce Edukacja odnaleźć można opis filozofii podejmowanych działań edukacyjnych - wpisane są one w założenia pedagogiki pamięci. Przyjęta koncepcja wpływa na kształt prowadzonych aktywności, można nawet powiedzieć, że wymusza ich formę. Uwzględnia podmiotowość osób uczących się i tworzy warunki do edukacji przez odkrywanie. Uczestnicy zajęć samodzielnie podejmują działania i wysiłek badawczy, w konsekwencji czego formułują sądy i wnioski. „Celem ogólnym pedagogiki pamięci jest inicjowanie procesów myślowych w trakcie zdobywania wiedzy na temat historii danego miejsca (z uwzględnieniem ogólnego tła historycznego)" (Pedagogika pamięci). 
Oferta edukacyjna Muzeum, z uwagi na podnoszoną tematykę, skierowana jest do uczniów klas starszych. Przygotowano dla nich szereg propozycji zajęć wykorzystujących różne formy kształcenia: wizytę w Muzeum, dni studyjne (zwiedzanie połączone $\mathrm{z}$ samodzielną pracą $\mathrm{w}$ archiwum lub bibliotece), warsztaty prowadzone metodą projektów, praktyki historyczne ukierunkowane, międzynarodowe spotkania młodzieżowe oraz seminaria edukacyjne. Zaplanowano szereg ciekawych i nowoczesnych zajęć prowadzonych z wykorzystaniem różnych środków dydaktycznych: nagrań video i filmów dokumentalnych, prezentacji multimedialnych i tekstów źródłowych. Zadbano również o nauczycieli. Dla nich powstał Pakiet edukacyjny do pobrania ze strony internetowej. Pomaga on przygotować klasę do wizyty w byłym niemieckim obozie koncentracyjnym. W skład pakietu wchodzą:

- publikacja pod redakcją Tomasza Kranza (2012) Wizyty edukacyjne w Państwowym Muzeum na Majdanku. Poradnik dla nauczycieli,

- płyta CD Edukacja pozaszkolna w Państwowym Muzeum na Majdanku. Jak przygotować, przeprowadzić i podsumować zajęcia dla uczniów pod redakcją Wiesława Wysoka zawierająca gotowe scenariusze zajęć i wskazówki ułatwiające ich przeprowadzenie,

- dziewięć kart z reprodukcjami muzealiów poobozowych, które mogą zostać wykorzystane w trakcie opisanej na płycie lekcji poprzedzającej wizytę na Majdanku.

Jest to najbardziej profesjonalnie przygotowana oferta spośród prezentowanych w niniejszym opracowaniu. Można ją pobrać w formie przygotowanego w wersji pdf katalogu, zawierającego szczegółowy opis sugerowanych działań. Należy podkreślić fakt, że edukatorzy zadbali nie tylko o atrakcyjność i nowoczesność przekazu, ale również o to, by uczniowie pragnący skorzystać z edukacyjnych zasobów Muzeum należycie przygotowali się do tej wizyty, co wydaje się bardzo istotne ze względu na podejmowaną tematykę. Mankamentem mogą być ceny zajęć - dużo wyższe niż w innych muzeach. Szczegółowy wykaz proponowanych tematów zamieszczono w tabeli 7.

Tabela 7. Oferta edukacyjna Muzeum na Majdanku

\begin{tabular}{|l|l|}
\hline \multicolumn{2}{|c|}{ Muzeum na Majdanku } \\
\hline Odpłatność & w zależności od formy zajęć ceny wahają się od 150 do 800 zł \\
\hline Liczebność grup & do 30 osób \\
\hline Metody i formy & lekcje muzealne, warsztaty, seminaria, projekty \\
\hline Cykliczność & zajęcia jednorazowe oraz cykle \\
\hline
\end{tabular}




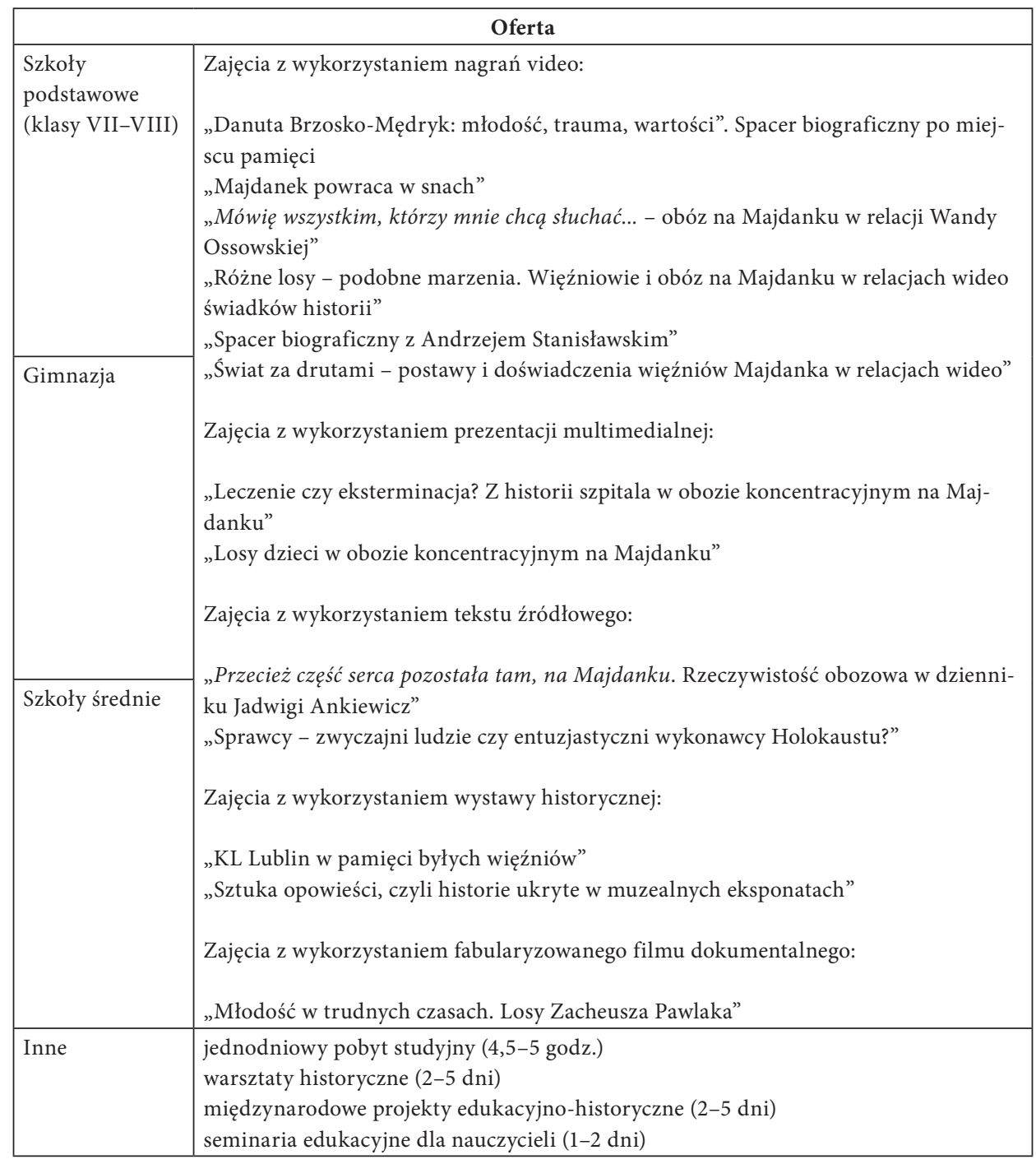

Źródło: opracowanie własne na podstawie informacji z oficjalnej strony internetowej Państwowego Muzeum na Majdanku (Oferta edukacyjna).

Ostatnią z poddanych analizie placówek jest najnowsze i najmniejsze zarazem lubelskie muzeum, a mianowicie Regionalne Muzeum Cebularza. Skoro mowa o wyróżniających to miejsce „naj”, należy dodać, ze ma ono najwęższą ofertę - taką samą dla wszystkich grup wiekowych. Można tutaj tylko zapoznać się $\mathrm{z}$ historią popularnego produktu regionalnego nazywanego skarbem lokalnym - cebularza. Jak czytamy na stronie Muzeum, jego misją jest „rozpowszechnia- 
nie wiedzy na temat cebularza w sposób przystępny oraz godny zapamiętania, co zwiększy rozpoznawalność tego ugruntowanego historycznie i kulturowo produktu regionalnego poza terenem Lubelszczyzny" (Misja). Wykonanie tej misji umożliwia przystępna forma interaktywnego pokazu prowadzonego przez Esterkę - bohaterkę jednej z lubelskich legend - oraz piekarza Franka. Uczestnicy zajęć mają okazję, by przygotować swoje cebularze (które z przyczyn sanitarnych nie są dopuszczane do konsumpcji), na zakończenie jest zaś przewidziana degustacja tego wyjątkowego pieczywa - upieczonego przez profesjonalistów. Muzeum, choć nowe, na stałe wrosło już w przestrzeń miasta, cieszy się dużym i wciąż rosnącym uznaniem różnych grup wiekowych: od przedszkolaków po zwiedzających Lublin zagranicznych turystów. Jest to jedyna placówka tego typu na terenie miasta (chociaż zajęcia polegające na przygotowywaniu potraw czy wypieków znajdują się też w ofercie skansenu).

Tabela 8. Oferta edukacyjna Regionalnego Muzeum Cebularza

\begin{tabular}{|l|l|}
\hline \multicolumn{2}{|c|}{ Regionalne Muzeum Cebularza } \\
\hline Odpłatność & pokaz: 12 zł/16zł \\
\hline Liczebność grup & do 30 osób \\
\hline Metody i formy & interaktywny pokaz, warsztaty \\
\hline Cykliczność & zajęcia jednorazowe \\
\hline \multicolumn{2}{|c|}{ Oferta } \\
\hline $\begin{array}{l}\text { Przedszkola i klasy I-III } \\
\text { podstawowych IV-VIII szkół } \\
\begin{array}{l}\text { Gimnazja } \\
\text { Szkoły średnie }\end{array}\end{array}$ & $\begin{array}{l}\text { interaktywny pokaz przybliżający uczestnikom legendę lubelskiego } \\
\text { produktu regionalnego - cebularza, połączony z wyrabianiem cebula- } \\
\text { rzy i degustacją }\end{array}$ \\
\hline
\end{tabular}

Źródło: opracowanie własne na podstawie informacji z oficjalnej strony internetowej Regionalnego Muzeum Cebularza (Krótko o Muzeum).

\section{PODSUMOWANIE}

Jak wynika z przeprowadzonej analizy, działania edukacyjne proponowane zorganizowanym grupom mają stałą i coraz mocniejszą pozycję w ofercie placówek muzealnych, w których powstają oddzielne komórki - działy edukacji zajmujące się przygotowywaniem ofert dla różnych odbiorców. Działania te odpowiadają charakterowi oraz profilowi poszczególnych placówek, a także specyfice regionu. Łączą różne wymiary edukacji (np. historyczną z regionalną). Autorzy scenariuszy zajęć mają na uwadze możliwości percepcyjne adresatów, w związku z tym oferta, 
przynajmniej z założenia, dostosowana jest do wieku odbiorców. Na stronach internetowych każdej z placówek zajęcia skatalogowane zostały w zestawy dedykowane konkretnym grupom wiekowym. Jednak, jak podkreślono przy charakterystyce zasobów edukacyjnych poszczególnych muzeów, scenariusze zajęć o tym samym tytule i opisie zawartości kierowane są do kilku grup wiekowych. Należy mieć nadzieję, że - zgodnie z deklaracjami złożonymi w Internecie - prowadzący dostosowują przekaz i jego formę do indywidualnych potrzeb odbiorców.

Zaczyna się też powoli uwidaczniać troska o komfort i dostępność zwiedzania przez osoby z niepełnosprawnościami. Zakres dostosowań i ułatwień dla takich osób szczegółowo opisano na razie tylko w jednej z zaprezentowanych placówek.

Nie można jednoznacznie ocenić proponowanych form zajęć jako nowoczesne lub przestarzałe. Niekiedy specyfika placówki narzuca rodzaj przekazu, choć jak dowodzi zespół przygotowujący ofertę edukacyjną w Muzeum na Majdanku, nawet niezwykle trudne tematy da się podejmować w nowoczesny i bardzo zróżnicowany sposób. Zdecydowanie można stwierdzić, że autorzy i prowadzący zajęcia odchodzą od tradycyjnych form wykładu, odczytu czy prelekcji (jeśli takie się pojawiają, to w trakcie zajęć kierowanych do młodzieży). Coraz częściej warsztaty prowadzone są z wykorzystaniem metod aktywizujących, by odwiedzający placówkę czynnie uczestniczyli w zajęciach, samodzielnie wykonywali pewne czynności i prace, w miarę możliwości w warunkach naturalnych. Efekty tych działań przyjmują często formę namacalną: wyrobów regionalnych, prac plastycznych, projektów itp. Bardzo istotne jest, że w trakcie zajęć wykorzystuje się przestrzenie muzealne. Edukacja w muzeum nie polega już tylko na tym, że kustosz głosi pogadankę, a następnie słuchacze z zadumą pochylają się nad gablotami. Zakres tematyczny proponowanych działań jest szeroki. Specyfika placówki i temat zajęć nierzadko stanowią tylko pretekst do dyskusji. Wnioski płynące z rozmów odnoszą się do uniwersalnych wartości, mają prowadzić uczestnika do refleksji nad łącznością między przeszłością a teraźniejszością.

Oferta edukacyjna współgra z podstawą programową. Skonstruowana została tak, by korzystać z niej mogli nie tylko poloniści czy historycy, ale również nauczyciele uczący innych przedmiotów. Ceny biletów i wysokość opłat za lekcje muzealne nie są wygórowane (wyjątek stanowi tu Muzeum na Majdanku), co sprawia, że ta forma urozmaicania edukacji wydaje się dostępna dla szerokiego grona odbiorców. Podsumowując, należy stwierdzić, że twórcze myślenie, kompetencje oraz ciekawość poznawcza pracowników działów edukacji lubelskich muzeów przyczyniły się do wykorzystywania tych placówek jako miejsc, w których można uzupełniać szkolną edukację, a przy okazji wciąż na nowo odkrywać „opowieści miasta". Stało się faktem to, co podkreślili we wstępie do Almanachu. Konceptów miejskich 2008-2012 (2012) jego redaktorzy: 
Peformerzy, pisarze, wizjonerzy wywołują z mroku to, co nierozpoznane, są niestrudzonymi wynalazcami opisywania fenomenu miasta. A dziś nie tylko artyści, ale i coraz liczniejsze wspólnoty jego mieszkańców i użytkowników proponują koncepty własne, wczoraj jeszcze niemożliwe (Kondrasiuk i in. 2012, s. 3).

\section{LITERATURA}

Bougsiaa H., Kopciewicz L., 2016, Dzieci w kulturze mobilnej. Partycypacja, uczenie się i emancypacja pokolenia „cyfrowych tubylców”. „Teraźniejszość - Człowiek Edukacja”, t. 19, nr 1 (73). Wrocław, Dolnośląska Szkoła Wyższa, 139-154.

Dział edukacji - historia, 2013. W: Muzeum Lubelskie w Lublinie - informacje ogólne, opublikowano: https://www.muzeumlubelskie.pl/Informacje_ogolne/Dzial_Edukacji_historia-1-690-82.html [dostęp: 21.06.2018].

Edukacja, 2013, opublikowano: https://www.muzeumlubelskie.pl/edukacja-4-22-22. html [dostęp: 21.06.2018].

Edukacja, 2019, opublikowano: http://skansen.lublin.pl/pl/edukacja/ [dostęp: 21.06.2018]. Hamer H., 1994, Klucz do efektywności nauczania: poradnik dla nauczycieli. Warszawa, Wydawnictwo Veda.

Kondrasiuk G. i in. (red.), 2012, „Kultura Enter” - Almanach. Koncepty miejskie 2008-2012. Lublin, Warsztaty Kultury, Centrum Kultury.

Kranz T. (red.), 2012, Wizyty edukacyjne w Państwowym Muzeum na Majdanku. Poradnik dla nauczycieli. Lublin, Państwowe Muzeum na Majdanku.

Krótko o Muzeum. W: Regionalne Muzeum Cebularza - z nami poznasz tradycje Lubelszczyzny, opublikowano: http://muzeumcebularza.com.pl/index.php/pl/ [dostęp: 06.07.2018].

Lekcje muzealne i wykłady, 2013. W: Muzeum Lubelskie w Lublinie. Oddziat - Muzeum Martyrologii „Pod Zegarem”, opublikowano: https://www.muzeumlubelskie.pl/ Lekcje_muzealne-1-383-37.html [dostęp: 03.07.2018].

Lublin, 2018. W: Wikipedia. Wolna encyklopedia, opublikowano: https://pl.wikipedia. org/wiki/Lublin [dostęp: 20.06.2018].

Mendel M., 2016, Kultura edukacyjna miasta: czego uczy globalny urbanizm? „Nauki o Wychowaniu. Studia Interdyscyplinarne", nr 2(3), 79-96.

Misja. W: Regionalne Muzeum Cebularza - z nami poznasz tradycje Lubelszczyzny, opublikowano: http://muzeumcebularza.com.pl/index.php/pl/ct-menu-item-3 [dostęp: 06.07.2018].

Morbitzer J., brw, Ekspertyza dotycząca zmian w sposobie uczenia się osób urodzonych po 1990 r. (pokolenie C, pokolenie homo mediens) z uwzględnieniem rekomendacji 
dotyczacych dostosowania metod i treści nauczania, w szczególności e-podręczników, do potrzeb i sposobu uczenia się wspótczesnych uczniów oraz wyzwań wynikających z rozwoju technologii informacyjnych. Warszawa, Ośrodek Rozwoju Edukacji.

Morbitzer J., 2012, O istocie medialności młodego pokolenia. „Neodidagmata”, nr 33/34. Poznań, Wydawnictwo UAM, 131-153.

Musiał E., 2016, Kreatywne nauczanie cyfrowych tubylców. „Annales Universitatis Paedagogicae Cracoviensis. Studia de Securitate et Educatione Civili” VI, 85-93. Myrdzik B., 2015, Przestrzeń edukacyjna jako „wędrujące pojęcie”. W: M. LatochZielińska, I. Morawska, M. Potent-Ambroziewicz (red.), Edukacja a nowe media. Lublin, Wydawnictwo UMCS, 13-23.

Muzeum. W: Słownikjęzyka polskiego PWN, opublikowano: https://sjp.pwn.pl/slowniki/ muzeum.html [dostęp: 20.06.2018].

Nadolska-Styczyńska A., 2016, Nie tylko lekcje i oprowadzanie. Kilka uwag o polskiej edukacji muzealnej i sposobach jej badania. "Journal of Urban Ethnology", nr 14, 95-111. Oferta, 2019. W: Muzeum Wsi Lubelskiej, opublikowano: http://skansen.lublin.pl/pl/ edukacja/oferta/1-3/ [dostęp: 29.06.2018].

Oferta edukacyjna, 2013a. W: Muzeum Lubelskie w Lublinie. Oddziat - Muzeum Historii Miasta Lublina, opublikowano: https://www.muzeumlubelskie.pl/Oferta_edukacyjna-4-152-35_152.html [dostęp: 27.06.2018].

Oferta edukacyjna, 2013b. W: Muzeum Lubelskie w Lublinie. Oddział - Muzeum Literackie w Lublinie. Filia - Muzeum Józefa Czechowicza, opublikowano: https://www. muzeumlubelskie.pl/Oferta_edukacyjna-4-51-36_51.html [dostęp: 30.06.2018].

Oferta edukacyjna, 2013c. W: Muzeum Lubelskie w Lublinie. Oddziat - Muzeum

Literackie w Lublinie. Filia - Muzeum Dworek Wincentego Pola, opublikowano: https://www.muzeumlubelskie.pl/OFERTA_EDUKACYJNA-1-330-38.html [dostęp: 29.06.2018].

Oferta edukacyjna. W: Majdanek. Miejsce pamięci i muzeum, opublikowano: http:// www.majdanek.eu/pl/education/oferta_edukacyjna/2 [dostęp: 04.07.2018].

O mieście, 2018, opublikowano: https://lublin.eu/lublin/o-miescie/ [dostęp: 20.06.2018]. Pater R., 2017, Edukacja muzealna - wychowanie do aktywnego uczestnictwa $w$ kulturze. „Parezja - Czasopismo Forum Młodych Pedagogów przy Komitecie Nauk Pedagogicznych", nr 1(7), 74-92.

Pater R., 2013, Edukacja muzealna dla dzieci. Alternatywne przestrzenie. „Edukacja Elementarna w Teorii i Praktyce: Kwartalnik dla Nauczycieli”, nr 4(30), 56-76. Pedagogika pamięci. W: Majdanek. Miejsce pamięci i muzeum, opublikowano: http:// www.majdanek.eu/pl/education/pedagogika_pamieci/1 [dostęp: 04.07.2018].

Peiper T., 1922, Miasto. Masa. Maszyna. „Zwrotnica”, nr 1, 23-31 [pozyskano z: http:// rcin.org.pl/Content/31751/WA248_31165_P-II-9_zwrotnica-o.pdf].

Pezda A., 2011, Koniec epoki kredy. Warszawa, Agora. 
Pilarska J., 2017, Locus educandi: miasto jako przestrzeń nieformalnej edukacji międzykulturowej. „Pogranicze. Studia Społeczne”, t. XXX, 154-166.

Szymborska W., 1977, Muzeum. W: tejże, Poezje. Warszawa, Państwowy Instytut Wydawniczy.

Trempała E., 2011, Edukacja formalna (szkolna) i edukacja nieformalna (równoległa, nieszkolna, pozaszkolna). „Edukacja - Pedagogia - Pedagogika - Pedagogizm Przegląd Pedagogiczny", nr 1, 95-104.

Wysok W. (red.), 2014, Edukacja pozaszkolna w Państwowym Muzeum na Majdanku. Jak przygotować, przeprowadzić i podsumować zajęcia dla uczniów. Lublin, Państwowe Muzeum na Majdanku.

Zduńczyk E., 2015, Człowiek w muzeum, czyli rzecz o wychowaniu, edukacji i rozrywce. „Fides et Ratio”, nr 1(32), 169-184.

Ustawa z dnia 21 listopada 1996 r. o muzeach, 1996. Dz.U., poz. 720.

\title{
LUBLIN FROM THE PEDAGOGUE'S PERSPECTIVE - RESOURCES OF THE CITY IN EDUCATIONAL ACTIVITIES. PART 1. MUSEUMS
}

\begin{abstract}
This text analyzes the educational offer of Lublin museums. An attempt was made to answer the question of whether, when planning educational activities, the employees of the centers take into account the needs of the young generation and the recommendations of didactics, or the effects of their work are attractive to children and youth. The description was supplemented with lists of proposals for classes offered to pupils of kindergartens and schools by institutions included in the Lublin Museum and the Open Air Village Museum, the Majdanek Museum and the Regional Onion Museum.
\end{abstract}

Keywords: museum education, Lublin, city space in education 